\title{
O Fôro no Estado Novo
}

João Arruda

Com insistência fala-se hoje em fazer um retrospecto das reformas empreendidas neste último decênio em nosso país. Ocupar-me-ei particularmente do que tem ocorrido no fôro.

Pretenderam Buckle e muitos outros luzeiros que o progresso, na história da humanidade, se desenvolve pela ação exclusiva do povo, dos governados, da massa popular: "Laissez aller, laissez passer", ou "Il mondo va da se". O mesmo sustentou-se em relação ao Direito, cuja origem, cuja vida foi atribuida à ação contínua, inconciente e indefessa do povo. Não obstante os estudos de Dicey e de tantos outros partidários da perfeita ou completa suficiência da ação da conciência popular, creio eu que razão teve EGGLESToN ao asseverar que uma reforma, uma transformação só se dá quando o govêrno intervem para a amparar. Fôra já dito que uma evolução só se consuma, uma reforma só se ultima quando ha um golpe revolucionário. Este porém é impotente no entender de EgGLEston, si o govêrno não presta seu braço forte em prol do progresso anelado. Assim, sustenta ele que só graças a Napoleão I tornou-se fecunda, e espalhou-se pelo mundo a transformação social iniciada pela revolução de 1789 .

Darei, tirados da nossa vida jurídica, dois exemplos que tornarão bem claro o pensamento de EgGLEston relativamente às instituições de Direito. Não são tirados destes úl- 
timos tempos. O $10^{\circ}$ é o relativo à conciliação. Este instituto, em que tanto confiavam os espíritos sonhadores, tornara-se um verdadeiro flagelo nos pleitos judiciais. A ação constante dos homens que trabalhavam no fôro tinha já patenteado que, sem abalo social, sem dificuldade, com um traço de pena, poderia ser cancelado do número de nossas instituições o péssimo empecilho à defesa dos direitos na tela judiciária. Veio a reforma de 1890 , que foi recebida com aplauso unânime, excluida, está claro, a opinião dos chicanistas, daqueles para quem a advocacia é um meio cômodo para despojar qualquer um do que é seu.

O outro caso é o da aplicação do R. 737 ao civel. Atendendo ao pedido de professores de Direito, juizes e advogados, e mesmo de todos enfim que, em boa fé, terçavam armas nos combates judiciais, houve algumas tentativas para libertar-nos das antiquadas leis avoengas que regiam o processo civel. Apontarei o tentâmen que se encontra na reforma de 1871. Veio afinal o dispositivo legal de 1890, dando o golpe radical, e correspondendo ao que era pedido por todos os homens de boa fé. Eis, exemplificando o. que sustenta Eggleston, o que fizeram nossos antepassados.

Que fizemos nós? Que fiz eu, visto como, nestes 10 anos, mourejei no fôro, fui lidador, do mesmo modo que o leitor, em pról do progresso jurídico de nossa pátria.

Acabo de referir-me à formação do Direito no seio do corpo social, até ser proclamado em lei. Direi agora sobre a sorte da lei em sua aplicação. Ao lado do poder legislativo, existe o poder regulamentador, que trata de adaptar a lei ao corpo social. Os regulamentos porém são insuficientes para perfeita execução do prescrito na lei. Aí surge a ação dos juizes, dos advogados, das autoridades administrativas e do povo em geral: a ação, em suma, das autoridades aplicadoras da lei e dos governados. Dizem os. mestres, que, ao lado da rigidez da lei, ha a plasticidade de seu conteudo. Foi sôbre a parte plástica das leis promul- 
gadas neste últimos 10 anos que particularmente se exerceu o nosos esfôrço. Mais do que qualquer das pessoas incumbidas da adaptação da lei ao corpo social, é o advogado a pessoa sôbre quem recai a maior responsabilidade.

Resumindo. Duas são as funções do jurista: criar o Direito que será transformado em lei, e produzir normas para a adaptação da lei ao corpo social. Só nós, cultores do Direito, habituados à seleção do que é de maior conveniência para a sociedade, sabemos quão árduo é criar normas consuetudinárias, e escolher dentre as populares, para formação do Direito scientífico, o que nos parece salutar à vida do corpo social. Os leigos vêem sómente, nos debates das assembléias, dos congressos, as hesitações, as lutas para encontrar o legislador as melhores fórmulas legais, as mais convenientes para a sociedade a que são destinadas. Não nos esqueçamos de que a publicidade de tais hesitações foi julgada prejudicial à força que devem ter as leis, e assim mantidas em segredo em relação à Constituição norteamericana. Si o Direito fixado em leis é formado em discussões públicas, com debates brilhantes, o consuetudinário, depurado, ou não, pelos homens da ciência, é organizado, nasce e evolve-se, por assim dizer, secretissimamente, sendo anónimos os seus autores, cujos importantes serviços são desconhecidos do povo assim favorecido pelos beneméritos de nossa classe.Eis o que fizemos nós advogados neste decênio em pról do Brasil.

Fóra da classe dos homens formados em Direito, é raro encontrar alguem que saiba quão dificil é cooperar com o poder regulamentador, ou, noutros termos, aplicar às espécies que surgem na sociedade os textos frios e mortos da lei. Cresce a dificuldade, quando a lei traz inovações para as quais não está preparada a massa popular a que a norma é destinada. Quanto lutámos nós para que fossem aceitas pelos leigos as ótimas reformas do Código Civil! Eis, 
repito, o serviço que a classe dos advogados prestou ao Brasil.

Refiro-me sempre ao que foi feito pelos advogados pela óbvia razão de ser eu tambem advogado, e consequentemente conhecer melhor nesse ramo nossa atividade juridica do que a que exerceram alguns de nossos colegas em outros gêneros de serviços a que se dedicam os homens formados em ciências jurídicas e sociais : magistratura, magistério, diplomacia etc.

Reatando, todavia, o fio de minha exposição, direi, pedindo vênia para fazer restrições ao que doutrina Eggleston, que, em geral, a lei nada mais representa do que a consagração do que está resolvido pelo espírito popular, nada mais faz do que formular o que julga o povo de seu interesse.

Por vezes, porém, sem dúvida, um espírito genial se anticipa ao movimento popular. Carlos Magno, em França, Pedro, o Grande, na Rússia, Mutsu Hito, no Japão, mostram que o progresso nem sempre se dá pelo modo indicado por Eggleston. Perigosissimos contudo são esses reformadores, quando não possuem a centelha com que a Providência dota certos guias da humanidade. Não nos esqueçamos da história do "asinus in tegulis" O que ocorre na vida social, tambem sucede, por vezes, no desenvolvimento do Direito. Dois exemplos confirmarão o que acabo de dizer, patenteando que nem sempre está o povo preparado para as ótimas reformas que veem dos altos poderes do Estado, notadamente do poder legislativo.

O 1. ${ }^{\circ}$ é tirado da Reforma Judiciária de 1871 a que acima aludi. Era ela, em muitas de suas inovações, inaplicavel na maior parte do Brasil. Ainda nos centros cultos, então raros em nossa pátria, encontraram as suas liberalissimas disposições relutância em pessoas de espírito sumamente conservador. Na "Gazeta Jurídica", publicada no Rio de Janeiro, contou seu redator, o notavel juriscon- 
sulto Carlos Frederico Marques Perdigão, quando entrava em vigor a lei, que, em certa comarca do Norte do Brasil, foi um inofensivo cidadão agredido por um desordeiro, gritando este, enquanto zurzia o pobre inocente: "Viva a Reforma Judiciária”! Outra lei, para cuja aplicação não estava preparado o Brasil, segundo os mestres de Direito Mercantil, era a excelente sôbre letra de câmbio. A prova de que tinham razão os doutos que tal afirmavam é que ainda hoje não teve ela, não obstante o esfôrço de tantos juristas que lhe fazem a apologia, exacta e fiel execução.

Si, na maioria dos casos, o Direito nasce e evolve-se no seio do povo até ser firmado em lei, si algumas outras vezes, embora excepcionalmente, é precedido por uma lei partida dos dirigentes, é fóra de dúvida que frequentemente é inconcientemente aplicado de conserva com uma lei em vigor, pelo povo e mesmo pelos juristas. Uma anedota narrada por EgGLeston tornará claro o que acabo de asseverar. Interrogado em Broocklyn um escolar sôbre o que era a Constituição dos Estados Unidos (What is the Constitution of the United States), respondeu que era a parte impressa nas costas dos livros, em tipo miúdo, e que ninguem lê: "It is that part in small print in the back of the book that nobody reads" E' o caso do "se non é vero..." O que nos interessa porém é que, sem ler a Constituição, todos a observam, todos a cumprem, ou são forçados a cumprí-la. Para não enfastiar o leitor, deixarei em esquecimento as leis imaginárias com que se ocupou LaLou, e que acodem frequentemente às necessidades da vida social, quando os governantes toscanejam.

Passarei ao retrospecto de nossas lutas neste decênio. Era uma lei nova, muito nova mesmo, no começo deste decênio, o nosso Código Civil, que eu acusei, pela Revista de Jurisprudência e por outras publicações jurídicas, de ser em excesso conservador. Os fatos posteriores deram-me razão, fazendo-se várias modificações em seu texto, por não acudir ele às necessidades do momento, dada a transforma- 
ção social por que passava o mundo. Emancipada a mulher, após a grande guerra, em consequência da tragédia universal, alterada profundamente a noção do direito de propriedade, entendendo-se ser uma antigualha a quiritária vigente em uma época de ultra individualismo, dificil era que o nosso Código correspondesse ás aspirações do mundo culto de então. Si, no Direito Civil, houvera essa profunda transformação, si o Código Civil, por sí só, pretendeu acolher as ideias dominantes no mundo jurídico, coisa diversa se deu no Direito Comercial. Não houve promulgação de um Código novo. Sómente foram decretadas leis esparsas em nossa coleção legislativa, mas o que é certo é que, à sombra do princípio da liberdade contratual, deu-se profunda modificação nos institutos bancários, nos do comércio internacional, e nos das relações entre comerciantes e auxiliáres do comércio. Falhou assim a generalidade da doutrina de Eggleston. Isto sem falar dos novos costumes nos pequenos negócios mercantis. Foram se acomodando os negociantes, graças a uma propaganda constante feita pelos comercialistas, pouco a pouco, ao uso do cheque e da letra de câmbio, sendo esta a preferida em São Paulo, quando a nota promissória tinha melhor acolhimento no Rio de Janeiro.

$\mathrm{Si}$, deixando o Direito Comercial, eu quizesse ocuparme com o Direito Industrial, recordando, ainda que resumidissimamente, sua evolução, efetuada com a vertiginosa rapidez da aeronave, tomaria ao leitor imprudentemente um tempo precioso. Tudo, com efeito, nele se mudou, havendo até o cuidado de alteração da linguagem, nâo mais se dizendo patrão, e sim empregador. O que nos interessou mais foi equiparar a lei o trabalhador intelectual ao manual, estendendo aos homens de letras os benefícios que havia conquistado a classe operária, ou a classe que se dava aos ofícios mecânicos.

Chego, porém ao ponto que interessa a todos os que me fazem a favor de ler este meu modesto retrospect de 
vem ter adivinhado que desejo referir-me ao Direito Processual.

Eternas eram as demandas em nosso fôro, mesmo sob o regimen do R. 737. Foi o Código Paulista de 1930 que acabou finalmente com a vergonhosa retenção de autos, por parte de advogados pouco escrupulosos, obtendo assim que desaparecesse da tela judiciária o principal fator da morosidade nos pleitos. Foi ele que diminuiu os casos em que era exigido o traslado, afinal abolido pelo novo Código Nacional. Sabem todos que, sob o regimen dos traslados, houve casos de colegas nossos, que por seu máo procedimento não recomendavam a honrada classe dos advogados, of erecerem, a título de documentos, várias volumosas folhas de jornais, ou grossos volumes de livros impressos, para impedirem, com este argumento ad crumenam ou ad terrendum, a remessa dos autos, por força de recurso, à 2. ${ }^{\mathrm{a}}$ instância. Quasi abolida está hoje tambem a carta de sentença, já dispensada na generalidade dos casos, pelo nosso Código de 1930, Código que, embora eivado de pequenos defeitos, foi obra patriótica e salutaríssima para nosso fôro. A carta de sentença era outra fonte de abusos por parte dos escrivães menos probos.

Não só para nós, mas tambem para nossa pátria, é importantissima a boa administração da justiça. Conhecida é a tese de que com boa administração de justiça e impostos moderados, dar-se-á fatalmente o progresso de um país, será feliz um povo. A boa justiça exige, sabemos tambem todos nós, que seja ela rápida e de pequeno custo. Quanto à celeridade, muito se fez, e se fará, protegidos os advogados honestos pelas leis ora em vigor. Tambem muito diminuiu o escândalo de transformarem certos juizes seus gabinetes em arquivos de cartórios, como se não existisse o art. $207 \S 5$ do Código Penal. Dentre as medidas benéficas adotadas pelo novo Código Nacional, ha a da audiência direta das testemunhas. No vol. 69 pags. 231 
e s. da "Revista dos Tribunais", mostrei o que era uma inquirição de testemunhas no ano da graça de 1929. O advogado que ditava o depoimento o deturpava, o escrivão, não raro, para beneficiar ao seu protegido, introduzia alguma coisa em prol de sua pretensão, e assim ia uma caricatura de depoimento para o juiz. Os advogados, quando arrazoavam, copiavam desse pretenso depoimento assim deformado o que lhes convinha, e o juiz limitava-se a ler o que cada um dos litigantes atribuira às testemunhas... Uma vergonha, uma indecência, em suma!... Agora é em público que fala a testemunha no cível, como já o era no crime, e assim ficou satisfeito o desiderato por mim manifestado às pags. 236 e 237 do referido volume 69 . A acusação que constantemente se repete no fôro contra o atual Código Nacional é a de que juizes e advogados não estão preparados para o executar. Considerarei por partes a acusação: quanto aos juizes e quanto aos advogados. Ha nela um fundo de verdade. Muitos dos leitores devem estar lembrados da figura daquele agrimensor de que nos fala Graça Aranha em seu romance Chanaan. Depois de haver feito a apologia do seu teodólito, à medida que se aproximava o dia do trabalho, do serviço no campo, ia se tornando irascível, até que, chegado o momento de ser iniciado o serviço, ficava intoleravel, verdadeiramente feroz. Declarava então imprestavel o instrumento, e fazia a medição com bússola e cipó. Conheço, e muitos de meus leitores conhecerão juizes que se tornam intratáveis quando teem de presidir assembléias de credores ou o tribunal do juri. Mas, felizmente, são raros: algum principiante ou velho escasso de inteligência. A maioria, ou quasi totalidade está em condições de resolver prontamente qualquer dificuldade na sessão de julgamento de um pleito, por muito árduo que seja o assunto. Passemos aos advogados. Os que trabalharam no juri, e sem dúvida não são muitos, sabem que é verdade digna do maior acatamento a que proclamou um luminar do fôro inglês, quando asseverou que "os discuross 
dos mestres raras vezes determinam a vitória em uma causa, e mesmo que pouco a afetam, mas que o resultado dela está, as mais das vezes, ligado à habilidade com que dirige o advogado o interrogatório das testemunhas" Com estas palavras, que faz suas, abre Wellman sua importantíssima obra "The Art of Cross Examination" Cito a opinião dos mestres em paises onde o procedimento é oral: a Inglaterra e os Estados Unidos. Os causídicos habituados às tricas da adulteração de depoimentos ficarão seguramente contrariados com a introdução do novo sistema no cível, mas logo se acomodarão, e aprenderão o que o tempo já ensinou aos que hoje se dedicam ao fôro criminal. Deixando o Código Nacional, farei alusão a um outro problema que foi posto em foco ultimamente pelo Presidente: Getúlio VARGas: refiro-me ao excesso de bachareis. Em meu modesto opúsculo "Quarenta Anos de Vida Forense", pags. 202 a 216, sustentei que não ha excesso de bachareis, mas sim má distribuição, por ficarem acumulados nas cidades mais populosas. Não imagina o leitor, quanto me tornei, por manifestar esta opinião, antipático aos de minha classe: diziam-me, irados, vários colegas que eu queria que eles fossem vegetar na roça, sem probabilidade de melhoria, enraizados em localidades onde não poderiam educar os filhos. Minha única defesa era a de que eu, com 25 anos de idade, em 1886, partira do Rio, onde fôra educado, e me embrenhára em Jaboticabal, indo até o Rio Preto, então sertão agreste. Ia na qualidade de juiz, é certo, mas, pouco depois, advoguei em Ribeirão Preto, quando a cidade estava longe de ser o culto centro que é hoje, isto é, um dos mais importantes do Estado. Concluia que, portanto, estava eu de boa fé. ., não aconselhando sinão o que eu mesmo fizera. Num outro ponto ainda tem razão o presidente Getúlio, e é quando afirma que nas comarcas do interior fazem falta aos nossos patrícios as luzes de um homem letrado. Na "Revista dos Tribunais", vol. 95, pg. 55 i. f., narro um fato que prova este asserto. Praza a 
Deus que seja o atual Chefe do Brasil mais feliz do que fui eu em minha opinião apresentada com inteira sinceridade. Passarei a outro problema. e são muitos os do fôro.

O problema do custo dos litígios é que não foi solvido, nem dele parece haver-se tratado. As despezas judiciais cresceram, e dizem os advogados que crescem constantemente. Entrando em execução o novo Código ha poucos meses, já a imprensa se queixa de que ele tornou ainda mais caro o processo. Estando eu afastado, desde algum tempo, das lides forenses, não tendo trabalhado sob o regimen do novo Código, não tenho idoneidade para dizer sôbre este ponto, em que são unissonos advogados e imprensa. O que sei é que, antes mesmo de entrar em vigor a nova lei processual, tal foi ao aumento do custo das causas, que ficou instituido o financiamento dos pleitos, em substituição da velha cessão de direitos a poderosos, com que se ocupavam as antigas leis processuais. $O$ benefício da justiça gratuita nenhum resultado apreciavel deu. Continuou pois o direito de litigar um luxo reservado aos ricos. O pobre não pode fazer valer judicialmente seus direitos conculcados, salvo nos casos de questões entre empregadores e empregados, ou patrões e operários, como se dizia antigamente, sendo este assunto hoje objeto das novas e múltiplas leis, e dos tribunais ultimamente criados para aplicação destas.

Termino este meu retrospecto oferecendo este problema extremamente árduo, qual o da justiça que não seja cara, que esteja ao alcance da bolsa de todos. E' gravíssimo, julgo eu, porque de todos os colegas que tenho sôbre ele consultado, ouço que os proventos de juizes, escrivães e oficiais de justiça não bastam para sua decente subsistência. Restam as taxas ao Estado: eliminadas estas, ainda seria nossa justiça inacessível à bolsa do pobre, e mesmo à dos que teem um fortuna média. A gravidade do problema que apresento afinal não é motivo para desânimo, mas 
para que lutemos afim de solvê-lo: lembremo-nos de que, manifestando aos governantes nossa opinião, filha da experiência, serviremos à nossa pátria, como dizem ter, da beirada de sua lareira, servido Adam Smith à Inglaterra mais do que qualquer dos ministros das finanças daquele culto país. Tenhamos a coragem de nossos avós, aqueles que desbravaram os ínvios sertões, e introduziram a civilização em nosso Estado.

Devemos os homens do fôro seguir a rota gloriosa que até hoje teem trilhado no desempenho de seus deveres. Eu, octogenário, exânime, caido à margem da estrada, qual soldado mal ferido, não posso mais marchar com meus companheiros de luta, mas sôbre eles fitarei meus olhos, embaciados pela idade, enquanto me restar um sôpro de vida, compartindo destarte o prazer de seus triunfos. 